\title{
PENGARUH PERGANTIAN MANAJEMEN, KEPEMILIKAN PUBLIK DAN FINANCIAL DISTRESS TERHADAP AUDITOR SWITCHING
}

\author{
Rosella Aprilia dan Bahtiar Effendi \\ Fakultas Ekonomi, Bisnis dan Ilmu Sosial, Universitas Matana \\ E-mail: bahtiar.effendi@matanauniversity.ac.id
}

\begin{abstract}
Auditor switching is the change of auditor or Public Accountant Firm which conducted by company. The purpose of this research is to get the empirical evidence about : (1) The influence of The Change of Management to Auditor Switching, (2) The influence of Public Ownership to Auditor Switching, (3) The influence of Financial Distress to Auditor Switching, The influence of The Change of Management, Public Ownership, and Financial Distress simultaneously to Auditor Switching, in Manufacture Companies which listed in Indonesia Stock Exchange (IDX) periode 2013 - 2017. The population in this research are The Manufacture Companies which listed on the Indonesia Stock Exchange in 2012-2016. Sampling technique that used in this study was purposive sampling technique, where as 32 manufacture companies are the sample in this research, with the total observation are 155 observations. Data analysis techniques are logistic regression analysis. The result of this research shows that : (1) The Changes of Management doesn't influence to Auditor Switching, (2) Public Ownership doesn't influence to Auditor Switching, (3) Financial Distress doesn't influence to Auditor Switching, (4) The Change of Management, Public Ownership and Financial Distress don't influence simultaneously to Auditor Switching.
\end{abstract}

Keywords : Auditor Switching, The Change of Management, Public Ownership, Financial Distress

\section{Pendahuluan}

Independensi seorang auditor merupakan hal yang penting bagi auditor ketika melaksanakan tugas pengauditan yang mewajibkan auditor memberi penilaian atas kewajaran laporan keuangan perusahaan kliennya. Independensi akan hilang jika auditor dan klien mempunyai hubungan pribadi, sehingga akan memengaruhi opini dan sikap mental mereka (Flint, 1988 dalam Nasser dan Wahid, 2006). Salah satu kekhawatiran atau ancaman seperti itu adalah masa perikatan audit (audit tenure) yang panjang. Sinason dan Shelton (2001) menemukan tingkat pertumbuhan klien secara signifikan memengaruhi masa perikatan audit. Giri (2010) menyatakan menerapkan auditor switching secara wajib mampu meningkatkan independensi auditor baik secara fakta, sikap maupun penampilan.

Penelitian tentang auditor switching ini dilakukan karena dilatarbelakangi oleh runtuhnya KAP Arthur Anderson di Amerika Serikat pada tahun 2001, sebagai salah satu KAP besar yang masuk dalam jajaran lima KAP terbesar di dunia atau Big 5 (Suparlan dan Andayani, 2010). KAP Arthur Anderson terlibat kecurangan dengan kliennya Enron sehingga hilangnya tingkat independensinya. Di Indonesia, kasus atas PT. Inovisi Infracom Tbk (INVS) mengganti KAP dimana sebelumnya KAP Jamaludin, Ardi, Sukimto dan rekan atas pelaksanaan audit laporan keuangan 2013 diganti dengan KAP Kreston International 
(Hendrawinata, Eddy Siddharta, Tanzil dan rekan) merupakan fenomena lain yang menjadi pertimbangan dalam penelitian ini. Pergantian KAP yang dilakukan oleh PT. Inovisi Infracom Tbk dikarenakan terdapat banyaknya kesalahan yang ditemukan dalam laporan keuangan perusahaan kuartal III-2014 yang berakibat pada dibekukannya perdagangan saham dari PT. Inovisi Infracom. Hal ini membuat PT. Inovisi Infracom Tbk mengambil keputusan untuk mengganti KAP yang telah mengaudit perusahaannya sebelumnya dengan KAP yang baru (Augustyvena, 2017).

Menurut teori agensi, Jensen dan Meckling (1976) dalam Suparlan dan Andayani (2010) menyatakan bahwa masalah agensi disebabkan oleh adanya perbedaan kepentingan dan asimetri informasi antara principal dan agent. Di satu pihak shareholders menginginkan pada hasil keuangan yang bertambah atau investasi mereka dalam hal ini pendapatan dividen yang besar. Namun di lain pihak, manajemen menginginkan adanya tambahan kompensasi ataupun bonus sehingga dapat menambah kepuasan mereka (Aprillia, 2013). Salah satu mekanisme yang mengikat adalah fungsi audit yang dilakukan oleh para profesional independen atas operasi dan pengungkapan informasi yang diberikan oleh manajemen (Watts dan Zimmerman, 1986; Willenborg, 1999; dalam Lin dan Liu, 2009). Informasi yang diberikan oleh manajemen kepada auditor dapat dipengaruhi oleh beberapa faktor, seperti pergantian manajemen, kepemilikan publik, serta financial distress. Karena itu, auditor switching ini merupakan salah satu mekanisme yang dapat dilakukan untuk meminimalkan konflik antara agen dengan pemilik dan untuk menumbuhkan kepercayaan satu sama lain.

Pergantian manajemen merupakan pergantian direksi perusahaan yang dapat disebabkan karena keputusan rapat umum pemegang saham atau direksi berhenti karena kemauan sendiri (Damayanti dan Sudarma, 2007). Menurut Sinarwati (2010) pergantian manajemen ini sering kali diikuti oleh perubahan kebijakan dalam perusahaan termasuk dalam hal pemilihan KAP. Manajemen yang baru berharap bahwa KAP yang baru lebih bisa diajak kerjasama dan lebih bisa memberikan opini seperti yang diharapkan oleh manajemen, disertai dengan adanya preferensi tersendiri tentang auditor yang akan digunakannya. Perusahaan akan mencari KAP yang selaras dengan kebijakan dan pelaporan akuntansinya (Nagy, 2005 dalam Sinarwati, 2010). Kepemilikan saham publik diukur dengan rasio jumlah saham yang dimiliki masyarakat (publik) dengan total saham. Rasio ini menunjukkan seberapa besar saham perusahaan yang dimiliki oleh publik (Simanjuntak dan Widiastuti, 2004). Carey et al. (2000) menyatakan proporsi kepemilikan saham non keluarga meningkat, maka timbul permintaan monitoring dan audit berkualitas. Guedhami et al. (2009) menemukan kepemilikan saham menyebar mempunyai pengaruh penting untuk memperoleh laporan keuangan yang berkualitas tinggi yang diwujudkan dalam pemilihan auditor.

Wruck (1990) mendefinisikan kesulitan keuangan (financial distress) sebagai sebuah situasi dimana arus kas tidak dapat memenuhi untuk membayar kewajiban saat ini ( $a$ situation where cash flow is insufficient to cover current obligations). Kewajiban yang dimaksud bisa saja kewajiban kepada pemasok bahan baku, hutang, pajak, hutang bank dan kewajiban lainnya. Schwartz dan Soo (1995) berpendapat bahwa perusahaan yang terancam bangkrut lebih sering melakukan auditor switching dari pada perusahaan yang tidak terancam bangkrut. Ketidakpastian dalam bisnis pada perusahaan- perusahaan yang terancam bangkrut (mempunyai kesulitan keuangan) menimbulkan kondisi yang mendorong perusahaan melakukan auditor switching.

Adapun rumusan masalah yang dihasilkan dalam penelitian ini adalah apakah pergantian manajemen, kepemilikan publik, dan financial distress berpengaruh terhadap auditor switching pada perusahaan manufaktur yang listing di BEI tahun 2013-2017. Dan tujuan dari penelitian ini adalah untuk menguji pengaruh pergantian manajemen, kepemilikan publik, dan financial distress terhadap auditor switching pada perusahaan 
manufaktur yang listing di BEI tahun 2013-2017.

Wijayani (2011) menjelaskan bahwa adanya manajemen yang baru mungkin juga diikuti oleh perubahan kebijakan dalam bidang akuntansi, keuangan, dan pemilihan KAP. Penelitian sebelumnya yang dilakukan oleh Sulistriarini dan Sudarno (2012), serta penelitian yang dilakukan oleh Anisa (2016) menunjukkan bahwa pergantian manajemen berpengaruh terhadap auditor switching. Namun, dalam penelitian Kurniasari (2014), begitu pula dalam penelitian Eriansyah dan Diniwahyu (2016) menunjukkan bahwa pergantian manajemen tidak berpengaruh terhadap auditor switching.

Kepemilikan saham menyebar mempunyai pengaruh penting untuk memperoleh laporan keuangan yang berkualitas tinggi yang diwujudkan dalam pemilihan auditor dari KAP (Guedhami et al., 2009). Kepemilikan publik memiliki pengaruh terhadap auditor switching pada penelitian yang dilakukan oleh Suparlan dan Andayani (2010) maupun pada penelitian yang dilakukan oleh Mahindrayogi dan Suputra (2016). Sedangkan kepemilikan publik tidak berpengaruh di dalam penelitian Aprillia (2013) dan Suryanti (2014). Auditor pada distressed clients memiliki masa audit yang lebih pendek dibandingkan dengan rekanrekan audit mereka pada klien yang lebih sehat dan pada gilirannya akan cenderung diganti (Pradhana dan Suputra, 2015). Nurcahyani (2013) serta Pratini dan Astika (2013) memberikan bukti empiris bahwa financial distress berpengaruh terhadap auditor switching. Hal ini berbanding terbalik dengan hasil empiris dari penelitian yang dilakukan oleh Suryanti (2014), Pradhana dan Suputra (2015) yang menyatakan bahwa auditor switching tidak berhasil dipengaruhi oleh faktor financial distress.

\section{Tinjauan Literatur dan Pengembangan Hipotesis}

Teori Keagenan. Jansen dan Meckling (1976) dalam Andra (2012) menyatakan bahwa hubungan keagenan adalah suatu kontrak dimana satu atau lebih orang (principal) melibatkan orang lain (agent) untuk melakukan beberapa layanan atas nama mereka dan kemudian mendelegasikan sebagian kewenangan pengambilan keputusan kepada agen tersebut. Sehingga para pemilik perusahaan atau pemegang saham menunjuk manajemen yang bertujuan untuk mengelola perusahaan yang dimilikinya. Salah satu mekanisme yang mengikat adalah fungsi audit yang dilakukan oleh para profesional independen atas operasi dan pengungkapan informasi yang diberikan oleh manajemen (Watts dan Zimmerman, 1986; Willenborg, 1999; dalam Lin dan Liu, 2009). Informasi yang diberikan oleh manajemen kepada auditor dapat dipengaruhi oleh beberapa faktor, salah satunya adalah karena adanya pergantian manajemen. Dalam Aprillia, 2013, Pergantian Manajemen baru ini bertujuan menerapkan kebijakan akuntansi baru dan biasanya disertai dengan adanya keputusan penggantian KAP. Faktor lain yang mempengaruhi manajemen dalam memberikan informasi kepada auditor, yaitu adanya faktor kepemilikan publik. Aprillia (2013), proporsi kepemilikan saham oleh publik yang besar dalam suatu perusahaan akan memberikan pengungkapan informasi yang lebih baik. Hal ini akan memberikan dorongan bagi manajemen untuk memberikan informasi yang sesuai dengan fakta kepada auditor. Selain faktor-faktor yang telah disebutkan di atas, faktor kesulitan keuangan (financial distress) juga merupakan faktor yang dapat memengaruhi manajemen memberikan informasi kepada auditor. Financial distress yang dialami suatu perusahaan dapat membuat manajemen berpotensi menyajikan informasi laporan keuangan yang bias. Oleh sebab itu, Auditor Switching ini merupakan salah satu mekanisme yang dapat dilakukan untuk meminimalkan konflik antara agen dengan pemilik dan untuk menumbuhkan kepercayaan satu sama lain.

Auditor Switching. Pergantian KAP atau auditor switching merupakan pergantian auditor atau Kantor Akuntan Publik yang dilakukan oleh perusahaan klien (Andra, 2012). Menurut 
Hermawan, 2013, dalam sisi perusahaan, auditor switching adalah suatu tindakan pengambilan keputusan yang direncanakan oleh perusahaan untuk meningkatkan nilai perusahaan dan keuntungan mereka. Tindakan auditor switching tersebut dilakukan dengan penuh pertimbangan karena akan berdampak besar bagi perusahaan, seperti : tingkat kepercayaan investor. Auditor Switching ini dapat disebabkan oleh beberapa faktor yang bisa berasal dari faktor klien maupun faktor auditor. Dalam Nurcahyani (2013), pergantian auditor dapat bersifat mandatory (wajib) dan dapat juga bersifat voluntary (sukarela). Pergantian mandatory (wajib) dilakukan karena ada peraturan pemerintah yang mengatur tentang kewajiban rotasi auditor. Jika pergantian secara voluntary (sukarela), maka faktor-faktor penyebab dapat berasal dari sisi klien (misalnya financial distress, manajemen yang gagal, perubahan ownership, Initial Public Offering, dan sebagainya) dan dari sisi auditor (misalnya fee audit, kualitas audit, dan sebagainya).

Pergantian Manajemen. Damayanti dan Sudarma (2007) menyatakan bahwa pergantian manajemen merupakan pergantian direksi perusahaan yang dapat disebabkan karena keputusan rapat umum pemegang saham atau direksi berhenti karena kemauan sendiri. Pergantian manajemen dapat dibedakan menjadi 2 yaitu pergantian rutin dan tidak rutin. Pergantian rutin adalah pergantian manajemen yang disebabkan habisnya masa kerja dewan direksi. Sedangkan, pergantian tidak rutin cenderung dilakukan karena adanya pertimbangan terhadap kondisi perusahaan, dimana stuktur manajemen yang ada tidak mampu mengelola perusahaan dengan baik, sehingga struktur yang ada diganti dengan struktur manajemen yang baru dengan harapan akan membawa perbaikan pada pengelolaan perusahaan. Selain itu, peleburan (merger) perusahaan dan penambahan pemegang saham baru juga merupakan penyebab perusahaan melakukan pergantian KAP (Hermawan, 2013). Menurut Sinarwati (2010) pergantian manajemen ini sering kali diikuti oleh perubahan kebijakan dalam perusahaan termasuk dalam hal pemilihan KAP. Manajemen yang baru berharap bahwa KAP yang baru lebih bisa diajak kerjasama dan lebih bisa memberikan opini seperti yang diharapkan oleh manajemen, disertai dengan adanya preferensi tersendiri tentang auditor yang akan digunakannya. Perusahaan akan mencari KAP yang selaras dengan kebijakan dan pelaporan akuntansinya (Nagy, 2005 dalam Sinarwati, 2010). Joher et al., (2000) menyatakan bahwa manajemen memerlukan auditor yang lebih berkualitas dan mampu memenuhi tuntutan pertumbuhan perusahaan yang cepat.

Kepemilikan Publik. Kepemilikan saham publik diukur dengan rasio jumlah saham yang dimiliki masyarakat (publik) dengan total saham. Rasio ini menunjukkan seberapa besar saham perusahaan yang dimiliki oleh publik (Simanjuntak dan Widiastuti, 2004). Kepemilikan saham oleh publik dinilai dari kepemilikan saham yang memiliki presentase kepemilikan saham dibawah 5\%, yang berada di luar saham manajemen dan tidak memiliki hubungan istimewa dengan perusahaan yang diteliti (Puspitasari, 2009). Carey et al. (2000) menyatakan proporsi kepemilikan saham non keluarga meningkat, maka timbul permintaan monitoring dan audit berkualitas. Guedhami et al. (2009) menemukan kepemilikan saham menyebar mempunyai pengaruh penting untuk memperoleh laporan keuangan yang berkualitas tinggi yang diwujudkan dalam pemilihan auditor. Kepemilikan saham oleh masyarakat akan mendorong perusahaan untuk berganti auditor ke KAP yang berkualitas (Aprillia, 2013).

Financial Distress. Wruck (1990) mendefinisikan kesulitan keuangan (financial distress) sebagai sebuah situasi dimana arus kas tidak dapat memenuhi untuk membayar kewajiban saat ini (a situation where cash flow is insufficient to cover current obligations). Kewajiban yang dimaksud bisa saja kewajiban kepada pemasok bahan baku, hutang, pajak, hutang bank dan kewajiban lainnya. Perusahaan pasti mempunyai kemungkinan untuk mengalami 
kesulitan dan besaran kemungkinan tersebut tergantung kepada kebijakan yang diambil para pengambil keputusan dan lingkungan perusahaan yang mendukung perusahaan menuju kesulitan keuangan (Anisa, 2016). Palepu (2004) mengungkapkan bahwa perusahaan yang rentan mengalami kesulitan keuangan (financial distress) adalah perusahaan yang resiko bisnisnya tinggi, yaitu perusahaan yang revenue dan income before tax-nya sangat dipengaruhi oleh kondisi perekonomian, serta perusahaan yang dapat dengan mudah kehilangan aset, yaitu perusahaan yang sebagian besar asetnya tergolong sebagai intangible asset seperti human capital dan brand image. Schwartz dan Soo (1995) berpendapat bahwa perusahaan yang terancam bangkrut lebih sering melakukan auditor switching dari pada perusahaan yang tidak terancam bangkrut. Ketidakpastian dalam bisnis pada perusahaanperusahaan yang terancam bangkrut (mempunyai kesulitan keuangan) menimbulkan kondisi yang mendorong perusahaan melakukan auditor switching. Sulistiarini dan Sudarno (2012) mengungkapkan pergantian KAP dapat disebabkan karena perusahaan tidak dapat memenuhi biaya audit yang dibebankan oleh KAP yang mengauditnya karena sedang menurunnya kondisi keuangan perusahaan. Dengan demikian, perusahaan yang sedang mengalami financial distress akan cenderung berganti KAP dibandingkan perusahaan yang sehat.

Pengaruh Pergantian Manajemen terhadap Auditor Switching. Pergantian manajemen biasa dilakukan oleh perusahaan-perusahaan besar yang go-public. Pergantian manajemen dilakukan dengan melihat kondisi perusahaan dimana struktur manajemen yang ada ternyata tidak mampu mengelola perusahaan dengan baik (Pradhana dan Suputra, 2015). Wijayani (2011) menjelaskan bahwa adanya manajemen yang baru mungkin juga diikuti oleh perubahan kebijakan dalam bidang akuntansi, keuangan, dan pemilihan KAP. Joher et al., (2000) menyatakan bahwa manajemen memerlukan auditor yang lebih berkualitas dan mampu memenuhi tuntutan pertumbuhan perusahaan yang cepat. Penelitian yang dilakukan oleh Anisa (2016), pergantian manajemen terbukti berpengaruh secara positif terhadap auditor switching. Hasil penelitian tersebut selaras dengan penelitian yang dilakukan oleh Sulistriarini dan Sudarno (2012) yang juga meneliti variabel pergantian manajemen terhadap pergantian KAP dimana hasil penelitian tersebut menunjukkan bahwa pergantian manajemen berpengaruh secara signifikan terhadap pergantian KAP. Namun, dalam penelitian yang dilakukan oleh Eriansyah dan Diniwahyu (2016), pergantian manajemen tidak berpengaruh terhadap auditor switching. Hasil penelitian yang dilakukan oleh Kurniasari (2014) juga memberikan bukti empiris berupa pergantian manajemen tidak terbukti secara signifikan memengaruhi KAP switching. Untuk menguatkan penelitian sebelumnya, penelitian ini berasumsi untuk memberikan hipotesis bahwa pergantian manajemen berpengaruh positif terhadap auditor switching.

\section{$\mathrm{H}_{1}$ : Pergantian Manajemen berpengaruh positif terhadap Auditor Switching}

Pengaruh Kepemilikan Publik terhadap Auditor Switching. Kepemilikan saham menyebar mempunyai pengaruh penting untuk memperoleh laporan keuangan yang berkualitas tinggi yang diwujudkan dalam pemilihan auditor dari KAP (Guedhami et al., 2009). Hal ini memberikan bukti empiris bahwa kepemilikan saham oleh masyarakat akan mendorong perusahaan untuk berganti auditor ke KAP yang berkualitas.

Penelitian yang dilakukan oleh Suparlan dan Andayani (2010) menunjukkan bahwa Kepemilikan Publik berpengaruh positif terhadap auditor switching. Mahindrayogi dan Suputra (2016) yang juga meneliti salah satu variabel independen berupa variabel kepemilikan publik terhadap auditor switching memberikan bukti empiris bahwa kepemilikan publik berpengaruh terhadap auditor switching. Namun, Kepemilikan Publik tidak berpengaruh secara signifikan terhadap pergantian auditor dalam penelitian yang dilakukan 
oleh Suryanti (2014). Hasil tersebut sesuai dengan penelitian yang dilakukan oleh Aprillia (2013) yang juga menunjukkan kepemilikan publik tidak berpengaruh terhadap auditor switching. Hal ini memberikan informasi bahwa variabel Kepemilikan Publik masih bersifat inkonsisten. Untuk menguatkan penelitian sebelumnya, penelitian ini berasumsi memberikan hipotesis bahwa kepemilikan publik berpengaruh positif terhadap auditor switching.

$\mathrm{H}_{2}$ : Kepemilikan Publik berpengaruh positif terhadap Auditor Switching

Pengaruh Financial Distress terhadap Auditor Switching. Penelitian yang dilakukan oleh Nurcahyani (2013) memberikan bukti empiris bahwa financial distress berpengaruh positif dan signifikan terhadap auditor switching. Hasil penelitian tersebut selaras dengan penelitian yang dilakukan oleh Pratini dan Astika (2013) yang juga menunjukkan bahwa financial distress berpengaruh positif terhadap pergantian auditor. Sedangkan, penelitian yang dilakukan oleh Pradhana dan Suputra (2015) justru memberikan bukti empiris bahwa financial distress tidak berpengaruh terhadap pergantian auditor. Penelitian lain yang menunjukkan hasil serupa dengan penelitian yang dilakukan oleh Pradhana dan Suputra (2015) bahwa financial distress tidak berpengaruh terhadap auditor switching adalah penelitian yang dilakukan oleh Suryanti (2014). Auditor pada distressed clients memiliki masa audit yang lebih pendek dibandingkan dengan rekan-rekan audit mereka pada klien yang lebih sehat dan pada gilirannya akan cenderung diganti (Pradhana dan Suputra, 2015). Schwartz dan Soo (1995) menyatakan bahwa perusahaan yang bangkrut lebih sering melakukan auditor switching dari pada perusahaan yang tidak bangkrut. Hal ini yang menjadi acuan penelitian ini memberikan hipotesis bahwa financial distress berpengaruh positif terhadap auditor switching.

\section{$\mathrm{H}_{3}$ : Financial Distress berpengaruh positif terhadap Auditor Switching}

Pengaruh Pergantian Manajemen, Kepemilikan Publik dan Financial Distress secara simultan terhadap Auditor Switching. Pergantian manajemen, kepemilikan publik, dan financial distress diasumsikan berpengaruh bersama-sama terhadap auditor switching. Adanya manajemen yang baru mungkin juga diikuti oleh perubahan kebijakan dalam bidang akuntansi, keuangan, dan pemilihan KAP (Wijayani, 2011). Hal tersebut mengasumsikan bahwa perusahaan semakin terdorong melakukan auditor switching ketika terjadinya pergantian manajemen. Begitu pula dengan kepemilikan publik yang mendorong perusahaan untuk melakukan auditor switching. Menurut Aprillia (2013), kepemilikan saham oleh masyarakat akan mendorong perusahaan untuk berganti auditor ke KAP yang berkualitas. Bersamaan dengan hal tersebut, financal distress juga diasumsikan dapat memengaruhi perusahaan melakukan auditor switching dimana Schwartz dan Soo (1995) menjelaskan bahwa perusahaan yang bangkrut lebih sering melakukan auditor switching dari pada perusahaan yang tidak bangkrut. Hal tersebut yang menjadikan dasar penelitian ini memberikan hipotesis bahwa pergantian manajemen, kepemilikan publik, dan financial distress berpengaruh secara simultan terhadap auditor switching.

$\mathrm{H}_{4}$ : Pergantian Manajemen, Kepemilikan Publik, dan Financial Distress berpengaruh secara simultan terhadap Auditor Switching

\section{Metode Penelitian}

Penelitian ini tergolong penelitian kuantitatif yaitu penelitian yang menggunakan data berbentuk angka. Data yang digunakan merupakan data sekunder dan sumber data yang digunakan berasal dari laporan keuangan perusahaan. Adapun sampel yang diteliti adalah perusahaan manufaktur yang listing di Bursa Efek Indonesia tahun 2013-2017 dengan metode 
purposive random sampling. Metode yang digunakan untuk menguji hipotesis yang diajukan dalam penelitian ini adalah metode analisis regresi logistik.

Pengukuran variabel dependen, auditor switching, dilakukan dengan memberi nilai 1 bagi perusahaan yang melakukan auditor switching dan nilai 0 jika tidak melakukan auditor switching.

Pergantian manajemen adalah pergantian presiden direktur perusahaan (Damayanti, 2007). Apabila perusahaan klien melakukan pergantian manajemen diberi kode 1 dan jika perusahaan klien tidak mengganti direksi diberi kode 0 .

Pengukuran variabel kepemilikan publik dapat dilihat dari persentase saham yang dimiliki oleh publik. Presentase saham yang dimiliki publik dilihat dari kepemilikan saham dibawah 5\%, yang berada di luar saham manajemen dan tidak memiliki hubungan istimewa dengan perusahaan yang diteliti (Puspitasari, 2009).

Pengukuran Financial distress menurut jurnal terdahulu yang diteliti oleh Pradhana dan Suputra tahun 2015 menggunakan rumus :

$$
\text { Debt }=\frac{\text { Total Liability }}{\text { total asset }} \times 100 \%
$$

\section{Hasil Penelitian dan Pembahasan}

Dari jumlah populasi sebanyak 147 perusahaan manufaktur, hanya 31 perusahaan manufaktur dengan total 155 sampel-lah yang sesuai dengan kriteria dalam penelitian ini. Adapun rinciannya sebagai berikut :

Tabel 4.1. Proses Seleksi Objek Penelitian

\begin{tabular}{|c|l|c|}
\hline No & \multicolumn{1}{|c|}{ Kriteria Pemilihan Sampel } & Jumlah \\
\hline 1 & Perusahaan manufaktur yang sudah listing di BEI. & 147 \\
\hline 2 & $\begin{array}{l}\text { Perusahaan manufaktur yang tidak menerbitkan laporan tahunan } \\
\text { secara lengkap selama tahun 2013-2017. }\end{array}$ & $(42)$ \\
\hline 3 & $\begin{array}{l}\text { Perusahaan manufaktur yang tidak mencantumkan data secara } \\
\text { lengkap selama tahun 2013-2017. }\end{array}$ & $(1)$ \\
\hline 4 & $\begin{array}{l}\text { Perusahaan manufaktur yang tidak menerbitkan laporan keuangan } \\
\text { bermata uang rupiah. }\end{array}$ & $(25)$ \\
\hline 5 & $\begin{array}{l}\text { Perusahaan manufaktur yang tidak melakukan auditor switching } \\
\text { minimal 1 kali selama tahun 2013-2017. }\end{array}$ & $(47)$ \\
\hline 6 & Perusahaan manufaktur yang memiliki ekuitas negatif & $(1)$ \\
\hline Jumlah Perusahaan Sampel & $\mathbf{3 1}$ \\
\hline Tahun Pengamatan & $\mathbf{5}$ \\
\hline Jumlah Observasi Pengamatan & $\mathbf{1 5 5}$ \\
\hline
\end{tabular}

Sumber: IDX, 2013-2017

Hasil statistik deskriptif penelitian ini tertera dalam tabel 4.2. berikut :

\begin{tabular}{lccccc}
\multicolumn{5}{c}{ Tabel 4.2. Deskripsi Variabel Penelitian } \\
\cline { 1 - 1 } $\begin{array}{c}\text { Varia } \\
\text { bel }\end{array}$ & $\mathbf{N}$ & $\begin{array}{c}\text { Mini } \\
\text { mum }\end{array}$ & $\begin{array}{c}\text { Maxim } \\
\text { um }\end{array}$ & Mean & $\begin{array}{c}\text { Std. } \\
\text { Deviation }\end{array}$ \\
\hline $\begin{array}{l}\text { (Y) } \\
\text { Switch }\end{array}$ & 155 & 0 & 1 & 0,37 & 0,484 \\
PM & 155 & 0 & 1 & 0,14 & 0,350 \\
KP & 155 & $1,76 \%$ & $70,60 \%$ & $25,3598 \%$ & $15,36962 \%$ \\
FD & $\underline{155}$ & $\underline{6,92 \%}$ & $\underline{92,61 \%}$ & $\underline{46,1803 \%}$ & $\underline{21,35882 \%}$ \\
\hline
\end{tabular}

Sumber : Data sekunder yang diolah 2018

Keterangan :

Switch = Auditor Switching 
$\mathrm{PM} \quad=$ Pergantian Manajemen

$\mathrm{KP} \quad=$ Kepemilikan Publik

FD $\quad=$ Financial Distress

Berdasarkan tabel di atas, terlihat bahwa auditor switching memiliki nilai rata-rata sebesar 0,37 atau $37 \%$, yang berarti hanya $37 \%$ perusahaan sampel yang melakukan auditor switching dalam periode pengamatan. Standar deviasi dari auditor switching adalah 0,484 atau $48,4 \%$. Nilai standar deviasi yang lebih besar dari nilai rata-rata menunjukkan bahwa variasi data variabel auditor switching besar. Auditor switching memiliki nilai terendah yaitu 0 dan nilai tertinggi yaitu 1.

Nilai terendah dari pergantian manajemen adalah 0 dan nilai tertinggi yaitu 1 . Nilai rata-rata dari pergantian manajemen yakni sebesar 0,14 atau $14 \%$. Ini berarti hanya $14 \%$ perusahaan sampel yang melakukan pergantian manajemen dalam periode pengamatan. Standar deviasi yang dimiliki oleh pergantian manajemen adalah 0,350 atau 35\%. Nilai standar deviasi yang lebih besar dibandingkan dengan nilai rata-rata menunjukkan bahwa variabel pergantian manajemen memiliki variasi data yang besar.

Variabel kepemilikan publik memiliki nilai terendah sebesar $1,76 \%$ serta nilai tertinggi sebesar 70,60\%. Nilai rata-rata dari variabel ini adalah 25,3598\%. Hal tersebut menujukkan rata-rata kepemilikan saham oleh publik dalam perusahaan sampel masih terbilang cukup kecil. Standar deviasi yang dimiliki oleh variabel kepemilikan publik ini adalah sebesar $15,36962 \%$. Nilai standar deviasi yang lebih kecil dibandingkan dengan nilai rata- rata menunjukkan bahwa variasi data variabel kepemilikan publik tergolong tidak besar.

Nilai terendah dari financial distress adalah sebesar 6,92\% dan nilai tertinggi sebesar 92,61\%. Financial distress memiliki rata-rata yakni 46,1803\% dan standar deviasi sebesar $21,35882 \%$. Nilai rata-rata yang mencapai $46,1803 \%$ menunjukkan bahwa hampir sebagian besar perusahaan sampel mengalami kesulitan keuangan, namun hal tersebut masih dapat dikatakan normal mengingat besaran persentase sampel perusahaan yang mengalami financial distress lebih kecil dibandingkan dengan sampel perusahaan yang tidak mengalami financial distress. Dan nilai standar deviasi yang lebih kecil daripada nilai rata-rata mengisyaratkan bahwa variasi data variabel financial distress tidaklah besar.

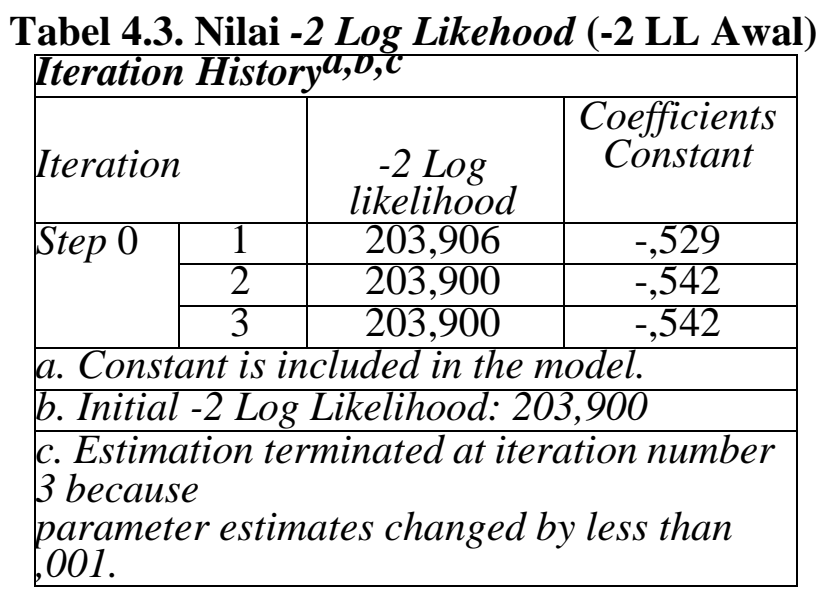

Sumber : Data sekunder yang diolah 2018

Tabel 4.4. Nilai -2 Log Likehood (-2 LL Akhir) Iteration History $a, b, c, a$ 


\begin{tabular}{|c|c|c|c|c|c|c|}
\hline \multirow{2}{*}{\multicolumn{2}{|c|}{$\begin{array}{l}\text { Iteratio } \\
n\end{array}$}} & \multirow{2}{*}{$\begin{array}{c}-2 \text { Log } \\
\text { likelihoo } \\
d\end{array}$} & \multicolumn{4}{|c|}{ Coefficients } \\
\hline & & & Constant & PM & KP & FD \\
\hline Ste & 1 & 202,271 & 080 &,- 296 &,- 007 & 008 \\
\hline & 2 & & &,- 327 & -007 & 009 \\
\hline & 3 & 202,249 &, 110 &,- 327 &,- 007 & \\
\hline \multicolumn{7}{|c|}{ a. Method: Enter } \\
\hline \multicolumn{7}{|c|}{$\begin{array}{l}\text { b. Constant is included in the model. } \\
\text { c. Initial -2 Log Likelihood: } 203,900\end{array}$} \\
\hline \multicolumn{7}{|c|}{$\begin{array}{c}\text { d. Estimation terminated at iteration number } \\
3 \text { because } \\
\text { parameter estimates changed by less than } \\
, 001 .\end{array}$} \\
\hline
\end{tabular}

Sumber : Data sekunder yang diolah 2018

Tabel 4.3. dan tabel 4.4. digunakan untuk menguji keseluruhan model fit (Overall Fit Model), dimana secara statistik menunjukkan perbandingan nilai antara -2 Log Likelihood (2LL) pada awal (Block number $=0)$ dengan nilai -2LL akhir $($ Block number $=1)$. Nilai -2LL awal adalah sebesar 203,906. Setelah dimasukkan ketiga variabel independen, maka nilai 2LL akhir mengalami penurunan menjadi sebesar 202,249. Hal ini berarti hipotesis nol diterima dan penurunan nilai -2 log likehood menunjukkan bahwa model penelitian ini dinyatakan fit, artinya penambahan-penambahan variabel yaitu Pergantian Manajemen, Kepemilikan Publik dan Financial Distress kedalam model penelitian ini akan memperbaiki model fit penelitian ini.

Tabel 4.5. Hosmer and Lemeshow Test

\begin{tabular}{|c|c|l|l|}
\hline Step & Chi-square & $d f$ & Sig. \\
\hline 1 & 3,762 & 8 &, 878 \\
\hline
\end{tabular}

Sumber : Data sekunder yang diolah 2018

Pengujian Kelayakan Model Regresi pada tabel 4.5. di atas menunjukkan nilai Chisquare sebesar 3,762 dengan nilai signifikansi sebesar 0,878>0,05. Hal ini menunjukkan bahwa tidak diperoleh adanya perbedaan antara data estimasi model regresi logistik dengan data observasinya. Hal ini berarti bahwa model tersebut sudah tepat dengan tidak perlu adanya modifikasi model dan dapat digunakan untuk memprediksi auditor switching.

Tabel 4.6. Koefisien Determinasi

\begin{tabular}{|c|c|c|c|}
\hline Step & $\begin{array}{c}-2 \text { Log } \\
\text { likelihood }\end{array}$ & $\begin{array}{c}\text { Cox \& Snell } \\
R \\
\text { Square }\end{array}$ & $\begin{array}{c}\text { Nagelkerke } R \\
\text { Square }\end{array}$ \\
\hline 1 & $202,249^{\mathrm{a}}$ &, 011 &, 014 \\
\hline
\end{tabular}

Sumber : Data sekunder yang diolah 2018

Dilihat dari tabel 4.6. nilai Cox \& Snell $R$ Square adalah sebesar 0,005 dan nilai Nagelkerke $R$ Square adalah 0,014. Hal ini menjelaskan bahwa variabel dependen, yakni auditor switching dapat dijelaskan oleh variabel- variabel independen dalam penelitian ini (pergantian manajemen, kepemilikan publik dan financial distress) adalah sebesar 1,4\%, sedangkan sisanya sebesar 98,6\% dijelaskan oleh variabel-variabel lain di luar model penelitian ini.

Tabel 4.7. Uji Multikolinieritas 


\begin{tabular}{|c|c|c|c|c|c|}
\hline \multicolumn{2}{|c|}{} & Constant & PM & KP & FD \\
\hline Step 1 & Constant & 1,000 &,- 238 &,- 699 &,- 810 \\
\cline { 2 - 6 } & PM &,- 238 & 1,000 &, 096 &, 111 \\
\cline { 2 - 6 } & KP &,- 699 &, 096 & 1,000 &, 277 \\
\cline { 2 - 6 } & FD &,- 810 &, 111 &, 277 & 1,000 \\
\hline
\end{tabular}

Sumber : Data sekunder yang diolah 2018

Hasil pengujian menunjukkan bahwa semua nilai korelasi antar variabel bebas masih memiliki nilai korelasi yang sangat rendah yaitu di bawah 0,90 . Hal ini menunjukkan tidak adanya masalah multikolinieritas.

Tabel 4.8. Hasil Uji Simultan

Omnibus Tests of Model Coefficients

\begin{tabular}{|c|c|c|c|}
\hline & $d \tilde{f}$ & Sig. \\
\hline \multicolumn{2}{|c|}{$\begin{array}{lll}\text { Chi-square } & \\
\text { Step } & \text { Step } & 1,651\end{array}$} & 3 &, 648 \\
\hline Block & 1,651 & 3 & ,648 \\
\hline Model & 1,651 & 3 & ,648 \\
\hline
\end{tabular}

Sumber : Data sekunder yang diolah 2018

Tabel 4.8. menunjukkan nilai chi square sebesar 1,651 dengan nilai signifikansi sebesar 0,648. Nilai signifikansi yang lebih besar dari 0,05, maka dapat disimpulkan bahwa pergantian manajemen, kepemilikan publik dan financial distress secara simultan tidak berhasil memengaruhi perusahaan untuk melakukan auditor switching.

Tabel 4.9. Hasil Analisis Regresi Logistik

\begin{tabular}{|c|c|c|c|c|c|c|c|c|c|}
\hline \multicolumn{10}{|c|}{ Variables in the Equation } \\
\hline & & \multirow[b]{2}{*}{$\mathrm{B}$} & \multirow[b]{2}{*}{ S.E. } & \multirow[b]{2}{*}{ Wald } & \multirow[b]{2}{*}{$\mathrm{df}$} & \multirow[b]{2}{*}{ Sig. } & \multirow[b]{2}{*}{$\operatorname{Exp}(B)$} & \multicolumn{2}{|c|}{$\begin{array}{c}95 \% \text { C.I. } \\
\text { for } E X P(B)\end{array}$} \\
\hline & & & & & & & & Lower & Upper \\
\hline \multirow{4}{*}{$\begin{array}{c}\text { Step } \\
1^{a}\end{array}$} & PM &,- 327 & ,498 & ,432 & 1 &, 511 &, 721 & ,272 & 1,913 \\
\hline & KP &,- 007 & 011 & ,424 & 1 &, 515 & ,993 & 971 & 1,015 \\
\hline & FD &,- 009 & ,008 & 1,236 & 1 & ,266 & ,991 & ,975 & 1,007 \\
\hline & $\begin{array}{c}\text { Cons } \\
\operatorname{tant}\end{array}$ & , 110 & ,569 & ,038 & 1 & ,846 & 1,117 & & \\
\hline
\end{tabular}

Sumber : Data sekunder yang diolah 2018

Keterangan :

Switch = Auditor Switching

$\mathrm{PM} \quad=$ Pergantian Manajemen

$\mathrm{KP} \quad=$ Kepemilikan Publik

FD $\quad$ Financial Distress

Persamaan :

SWITCH $=0,110-0,327 P M-0,007 \mathrm{KP}-0,009 F D$

Pada tabel 4.9., variabel pergantian manajemen memiliki nilai koefisien sebesar 0,327 dengan nilai signifikansi sebesar 0,511. Nilai signifikansi variabel pergantian manajemen (PM) yang lebih besar dari 0,05 mengartikan bahwa $\mathrm{H} 0$ diterima. Jadi pergantian manajemen tidak berpengaruh terhadap auditor switching. Hasil penelitian ini selaras dengan penelitian yang dilakukan oleh Suparlan dan Andayani (2010), Kurniasari (2014), Eriansyah 
dan Diniwahyu (2016). Namun hasil penelitian ini bertentangan dengan hasil penelitian yang dilakukan oleh Wijayani (2011), Pradhana dan Suputra (2015), Anisa (2016).

Menurut Nicklos (2000) dalam Kawijaya dan Juniarti (2002), alasan variabel pergantian manajemen tidak terbukti menyebabkan auditor switching karena pergantian manajemen merupakan perubahan yang terletak di dalam dan dikendalikan oleh organisasi, yang meliputi perubahan dalam hal teknologi, visi misi perusahaan, restrukturisasi tenaga kerja, kerjasama dengan perusahaan lain atau mengadan program baru. Sedangkan keputusan untuk melakukan auditor switching merupakan perubahan yang terjadi di luar organisasi.

Walaupun pergantian manajemen juga berperan dalam menentukan pergantian auditor, namun pergantian manajemen dalam suatu perusahaan tersebut tidak selalu diikuti dengan pergantian kebijakan perusahaan, dalam hal ini adalah kebijakan auditor switching. Hal tersebut mengindikasikan bahwa kebijakan dan auditor lama tetap dapat diselaraskan dengan kebijakan manajemen baru dengan cara melakukan negosiasi ulang antara kedua belah pihak (Damayanti dan Sudarma, 2008).

Variabel kepemilikan publik (KP) yang juga dapat dilihat dari tabel 4.9., memiliki nilai koefisien sebesar -0,007 dengan nilai signifikansi sebesar 0,515. Karena nilai signifikansi variabel kepemilikan publik (KP) yang lebih besar dari 0,05, maka dapat dinyatakan bahwa $\mathrm{H} 0$ diterima. Jadi kepemilikan publik tidak berpengaruh terhadap auditor switching. Hasil penelitian ini sesuai dengan hasil penelitian yang dilakukan oleh Sulistriarini dan Sudarma (2010), Aprillia (2013), Suryanti (2014) yang menyatakan bahwa kepemilikan publik tidak berpengaruh terhadap auditor switching. Sedangkan penelitian yang dilakukan oleh Suparlan dan Andayani (2010) serta Mahindrayogi dan Suputra (2016) memiliki hasil yang bertentangan dengan penelitian ini. Aprillia (2013) menjelaskan bahwa semakin besar jumlah saham yang dimiliki oleh publik, yang dilihat dari persentase saham publiknya, maka semakin mendorong perusahaan untuk menggunakan KAP yang berkualitas yaitu KAP Big Four. Namun data dalam penelitian ini menunjukkan bahwa sebagian besar sampel perusahaan yang menjadi observasi dalam penelitian ini memiliki persentase kepemilikan publik yang tergolong cukup kecil, sehingga hasil penelitian ini menunjukkan bahwa kepemilikan saham oleh publik tidak lantas mendorong perusahaan untuk melakukan auditor switching. Selain itu, perusahaan menganggap dengan seringnya melakukan auditor switching dapat menimbulkan anggapan negatif yang dapat mengganggu citra perusahaan (Sulistriarini dan Sudarno, 2012).

Nilai signifikansi dari variabel financial distress (FD) yang tertera pada tabel 4.9. adalah sebesar 0,266 dengan nilai koefisien -0,009. H0 diterima karena nilai signifikansi financial distress (FD) yang lebih besar dari 0,05. Hal ini berarti variabel financial distress tidak berhasil memengaruhi auditor switching. Hasil ini konsisten dengan penelitian yang dilakukan oleh Wijayani (2011), Sulistriarini dan Sudarno (2012), Pradhana dan Suputra (2015), Mahindrayogi dan Suputra (2016), namun tidak dengan penelitian yang dilakukan oleh Sinarwati (2010), Nurcahyani (2013), Pratini dan Astika (2013) yang memiliki hasil berbanding terbalik dengan penelitian ini. Perusahaan dalam kondisi financial distress cenderung tidak melakukan auditor switching, ini disebabkan pergantian auditor pada suatu perusahaan yang terlalu sering akan meningkatkan fee audit (Nasser et. al, 2006). Selain itu, menurut Mahindrayogi dan Suputra (2016), reputasi dari sebuah perusahaan akan dipertanyakan ketika terjadi kecenderungan perusahaan untuk mengganti KAP saat terjadi penurunan kinerja keuangan dalam perusahaan. 


\section{Simpulan dan Saran}

Simpulan. Penelitian ini bertujuan untuk menguji pengaruh pergantian manajemen, kepemilikan publik dan financial distress terhadap auditor switching pada Perusahaan Manufaktur yang Listing di BEI Tahun 2013 - 2017. Hasil penelitian menunjukkan bahwa Hasil uji hipotesis 1 (satu) dengan menggunakan regresi logistik menunjukkan bahwa pergantian manajemen tidak berpengaruh secara signifikan terhadap auditor switching. Hasil uji hipotesis 2 (dua) dengan menggunakan regresi logistik menunjukkan bahwa kepemilikan publik tidak berpengaruh secara signifikan terhadap auditor switching. Hasil uji hipotesis 3 (tiga) dengan menggunakan regresi logistik menunjukkan bahwa financial distress tidak berpengaruh secara signifikan terhadap auditor switching. Hasil uji hipotesis 4 (empat) dengan menggunakan regresi logistik menunjukkan bahwa pergantian manajemen, kepemilikan publik, dan financial distress secara simultan tidak berpengaruh secara signifikan terhadap auditor switching.

Keterbatasan. Penelitian ini memiliki beberapa keterbatasan, yaitu (1) Objek penelitian hanya berfokus kepada perusahaan manufaktur saja, sehingga hasil ini tidak dapat mewakili sektor-sektor lainnya.(2) Variabel corporate governance yang digunakan hanya menggunakan proksi pergantian manajemen dan kepemilikan publik, namun proksi-prosi dari corporate governance lainnya masih bervariasi yang tidak diteliti dalam penelitian ini yang mungkin dapat memengaruhi auditor switching. (3) Jumlah periode pengamatan hanya selama 5 tahun, yakni tahun 2013 - 2017, karena untuk memprediksi perusahaan melakukan auditor switching lebih baik jangka waktunya cukup panjang.

Saran. Saran-saran yang dapat dipertimbangkan dan diimplementasikan oleh berbagai pihak, yakni sebagai berikut : (1) Bagi regulator, penelitian ini diharapkan dapat menjadi bahan pertimbangan ketika regulator akan menentukan kebijakan baru berkaitan dengan auditor switching dalam suatu perusahaan dengan menimbang aspek-aspek yang diteliti dalam penelitian ini. (2) Bagi perusahaan, diharapkan penelitian ini dapat dijadikan referensi dalam pengambilan keputusan di masa yang akan datang, terutama kebijakan mengenai auditor switching, yakni dengan melakukan auditor switching secara wajar, tidak terlalu sering dan tidak pula terlalu jarang. (3) Untuk penelitian selanjutnya, diharapkan untuk meneliti objek penelitian yang lebih beragam, seperti perusahaan sektor keuangan, perusahaan properti dan real estate guna mendapatkan hasil yang lebih beragam dari berbagai jenis perusahaan terkait dengan auditor swithing. Selain itu, proksi corporate governance yang digunakan juga dapat bervariasi seperti dengan menambahkan atau mengganti dengan proksi ukuran dewan komite audit, ukuran dewan komisaris. Penambahan periode penelitian juga dapat dipertimbangkan untuk penelitian selanjutnya, sehingga dapat melihat kecenderungan auditor switching yang dilakukan oleh perusahaan dalam jangka waktu yang lebih panjang.

\section{DAFTAR PUSTAKA}

Abidin, Shamharir, Ishaya, Ishaku Vandi \& M. Nor, Mohamad Naimi. (2016). The Association between Corporate Governance and Auditor Switching Decision. International Journal of Economics and Financial.

Agoes, Sukrisno. (2012). Auditing Petunjuk Praktis Pemeriksaan Akuntan Oleh Akuntan Publik, Jilid 1, Edisi Keempat. Jakarta: Salemba Empat.

Andra, Ichlaisa Nurul. (2012). Faktor-Faktor yang Mempengaruhi Auditor Switching Setelah Ada Kewajiban Rotasi Audit di Indonesia. Skripsi. Universitas Diponegoro, Semarang. 
Anisa, Norma. (2016). Analisis Keputusan Perusahaan Dalam Melakukan Pergantian Kantor Akuntan Publik (Studi Empiris Pada Perusahaan Manufaktur yang Terdaftar di BEI Periode 2012-2014). Naskah Publikasi. Fakultas Ekonomi Dan Bisnis Universitas Muhamadiyah Surakarta.

Aprillia, Ekka. (2013). Analisis Faktor-Faktor yang Mempengaruhi Auditor Switching. Jurnal Fakultas Ekonomi Universitas Negeri Semarang.

Arens, A.A., Elder, R.J., Beasley \& M.S., Jusuf, A.A. (2009). Auditing and Assurance Service: An Indonesian Adaption. Singapore: Pearson Prentice Hall.

Augustyvena, Endistria Verosa. (2017). Pengaruh Pergantian Manajemen, Opini Audit, dan Kesulitan Keuangan (Financial Distress) Perusahaan Terhadap Pergantian Auditor (Auditor Switching). Jurnal Ekonomi. Sekolah Tinggi Ilmu Ekonomi Perbanas Surabaya.

Becker, Connie L., Defond, Mark L., Jiambalvo, James \& Subramanyan, K. R. (1998). The Effect of Audit Quality on Earnings Management. Contemporary Accounting Research.

Bewley, K., Chung, J., \& McCracken, S. (2008). An Examination of Auditor Choice Using Evidence from Andersen's Demise. International Journal of Auditing, 12.

Bougie, \& Sekaran. (2013). Research Methods for Business: A skill Building Approach Edisi 5. New York: John Wiley@ Sons.

Cadbury Report. (1992). Report of The Committee on The Financial Aspect of Corporate Governance.

Carey, P., Simet, R., \& Tanewski, G. (2000). Voluntary Demand for Internal and External Auditing by Family Businesses. Auditing: A Journal of Practice and Theory.

Damayanti, S. \& M. Sudarma. (2007). Faktor-Faktor yang Mempengaruhi Perusahaan Berpindah Kantor Akuntan Publik. Simposium Nasional Akuntansi 11, Pontianak. IAI.

DeFond, M.L. (1992). The Association Between Changes in Client Firm Agency Costs and Auditor Switching. Auditing: A Journal of Practice \& Theory, 11(1).

Effendi, Bahtiar. (2018). Pengaruh Ukuran Perusahaan dan Ukuran KAP terhadap Audit Delay. At Negotium Procuratio: Jurnal Bisnis dan Manajemen, 4(1), 1-11.

Effendi, Bahtiar. (2019). Kualitas Audit, Kondisi Keuangan, Ukuran Perusahaan dan Penerimaan Opini Audit Going Concern. Owner: Jurnal Riset dan Akuntansi, 3(1), 915.

Effendi, Bahtiar. (2019). Profitabilitas, Solvabilitas dan Audit Delay Pada Perusahaan Consumer Goods yang Terdaftar di BEI. Owner: Jurnal Riset dan Akuntansi, 2(2), 100-108.

Effendi, Bahtiar. (2019). Kondisi Keuangan, Opinion Shopping dan Opini Audit Going Concern Pada Perusahaan Pertambangan yang Terdaftar di BEI. STATERA: Jurnal Akuntansi dan Keuangan, 1(1), 34-46.

Eriansyah, Ikhsan \& Dini Wahyu. (2016). Pengaruh Opini Audit, Ukuran KAP, dan Pergantian Manajemen Terhadap Pergantian Auditor (Studi Empiris pada Perusahaan Manufaktur yang Terdaftar di Bursa Efek Indonesia Periode 2010 - 2014). EProceeding of Management, 3(3).

FCGI. (2008). Corporate Governance Suatu Pengantar: Peranan Dewan Komisaris dan Komite Audit Dalam Pelaksanaan Corporate Governance.

Giri, Efraim Ferdinan. (2010). Pengaruh Tenur Kantor Akuntan Publik (KAP) dan Reputasi KAP Terhadap Kualitas Audit: Kasus Rotasi Wajib Auditor di Indonesia. Jurnal Seminar Akuntansi Nasional 13, Purwokerto. IAI.

Ghozali, Imam. (2011). Aplikasi Analisis Multivariate dengan Program IBM SPSS 19. Semarang: Universitas Diponegoro. 
Guedhami, O., Pittman, J.A. \& Saffar, W. (2009). Auditor choice in privated firms: Empirical evidence on the role of state and foreign owners. Journal of Accounting \& Economics. 48.

Hartono. (2005). Hubungan Teori Signaling dengan Underpricing Saham Perdana di Bursa Efek Jakarta. Jurnal Bisnis dan Manajemen, 5(1).

Hermawan, Y. Dadi. (2013). Analisis Faktor-Faktor yang Mempengaruhi Pergantia KAP Upgrade, Downgrade, dan Samegrade di Indonesia. Skripsi. Fakultas Ekonomi Universitas Indonesia, Jakarta.

Hudaib, M. \& Cooke, T.E. (2005). The Impact of Managing Director Changes and Financial Distress on Audit Qualification and Auditor Switching. Journal of Business Finance \& Accounting, 32(9).

Https://ekonomi.kompas.com. Terindikasi Kasus Korupsi dan Pajak, India Cabut 100.000 Izin Usaha. Diakses pada Januari 2018.

Https://id.wikipedia.org/wiki/Tata_kelola_perusahaan. Diakses pada Januari 2018.

Ikatan Akuntan Indonesia. (2009). Standar Akuntansi Keuangan. Jakarta : Salemba Empat.

Ikatan Akuntan Indonesia. (2011). Standar Profesional Akuntan Publik. Jakarta : Salemba Empat.

Ismail, S., H. J. Aliahmed, \& A. M. Nassir. (2008). Why Malaysian Second Board Companies Switch Auditor?: Evidence of Bursa Malaysia. International Research Journal of Finance.

Johari, Muhammad Habib Takeshi \& P. Basuki Hadiprajitno. (2015). Pengaruh Corporate Governance Terhadap Voluntary Auditor Switching (Studi Empiris pada Perusahaan Manufaktur, Perdagangan, Jasa, dan Investasi yang Terdaftar di Bursa Efek Indonesia pada Tahun 2009 - 2013). E-jurnal Universitas Diponegoro, 4(4). (http://ejournalsl.undip.ac.id/index.php/accounting).

Joher, H.S.M., Ali, M., \& Annuar, M.N. (2000). The Auditor Switch Decision of Malaysian Listed Firms: An Analysis of Its Determinants \& Wealth Effect.

Kawijaya, Nelly \& Juniarti. (2002). Faktor-Faktor yang Mendorong Perpindahan Auditor (Auditor Switch) pada Perusahaan-Perusahaan di Surabaya dan Sidoarjo. Jurnal Akuntansi dan Keuangan, 4(2).

Keputusan Menteri Keuangan Nomor 359/KMK.06/2003 tentang Jasa Akuntan Publik. 2003.

Keputusan Menteri Keuangan Republik Indonesia Nomor 17/PMK.01/2008 tentang Jasa Akuntan Publik. 2008.

Kurniasari, Desi. (2014). Faktor-Faktor Terkait KAP Switching yang Dilakukan Perusahaan Secara Voluntary. Jurnal Fakultas Ekonomi dan Bisnis Universitas Dian Nuswantoro. Semarang.

Lin, Z.J., \& Ming, L. (2009). The Impact of Corporate Governance on Auditor choice Evidence From China. Journal of International Accounting, Auditing \& Taxation, 18.

Mahindrayogi, Komang Trisdia \& IDG Dharma Suputra. (2016). Faktor-Faktor yang Memengaruhi Voluntary Auditor Switching Pada Perusahaan Manufaktur Di Bursa Efek Indonesia. E-Jurnal Akuntansi Universitas Udayana, 14(3).

Mulyadi. (2009). Auditing. Jakarta: Salemba Empat.

Mulyadi, Puradiredja. (2014). Auditing dan Pemeriksaan Akuntansi. Edisi Pertama. Jakarta : Salemba Empat.

Nagy, A.L., (2005). Mandatory Audit Firm Turnover, Financial Reporting Quality and Client Bargaining Power, Accounting Horzons, 19(2).

Nasser, Abdul \& Emelin Abdul Wahid. (2006). Auditor-Client Relationship: The Case of Audittenure and Auditor Switching in Malaysia. Managerial Auditing Journal, 21(7).

Nurcahyani, Yulia. (2013). Pengaruh Tingkat Pertumbuhan Perusahaan, Financial Distress, 
Dan Ukuran KAP Terhadap Pergantian Auditor (Studi Empiris Pada Perusahaan Manufaktur yang Terdaftar di Bursa Efek Indonesia Tahun 2008-2011). Fakultas Ekonomi Dan Bisnis Universitas Muhammdiyah Surakarta.

Palepu, Krisna G., Healy, Paul M., \& Bernard Victor L., (2004). Business Analysis and Valuation, Third Edition, South-Western, USA.

Pradhana, Made Aditya Bayu \& I.D.G. Dharma Suputra. (2015). Pengaruh Audit Fee, Going Concern, Financial Distress, Ukuran Perusahaan, Pergantian Manajemen Pada Pergantian Auditor. E-Jurnal Akuntansi Universitas Udayana, 11(3).

Prahesty, Siska, (2011). Analisis Faktor-Faktor yang Mempengaruhi Ketepatan Waktu Pelaporan Keuangan. Fakultas Ekonomi Universitas Diponegoro, Semarang.

Pratini, I. \& Astika, I. (2013). Fenomena Pergantian Auditor di Bursa Efek Indonesia. EJurnal Akuntansi Universitas Udayana, 5(2).

Peraturan Pemerintah No. 20 Tahun 2015 Tentang Praktik Akuntan Publik.

Puspitasari, Diana. (2009). Analisis Pengaruh CAR, NPL, PDN, NIM, BOPO, LDR, Dan Suku Bunga SBI Terhadap ROA. Tesis. Universitas Diponegoro, Semarang.

Schwartz, K.B. \& Soo, B.S. (1995). An Analysis of Form 8-K Disclosures of Auditor Changes by Firms Approaching Bankruptcy. Auditing : A Journal of Practice \& Theory, 14(1), 125-135.

Sekaran, Uma \& Bougie, Roger. (2010). Research Method for Business A Skill Building Approach (5th Edition). United Kingdom : John Wiley \& Sons Ltd.

Simanjuntak, Binsar H \& Lusy Widiastuti. (2004). Faktor-faktor yang Mempengaruhi Kelengkapan Pengungkapoan Laporan Keuangan pada Perusahaan Manufaktur yang terdaftar di BEJ, Jurnal Riset Akuntansi Indonesia, 7(3).

Sinarwati, Ni Kadek. (2010). Mengapa Perusahaan Manufaktur yang Terdaftar di BEI Melakukan Pergantian Kantor Akuntan Publik?. Simposium Nasional Akuntansi XIII.IAI.

Sinason, D.H., J.P. Jones \& S.W. Shelton. (2001). An Investigation of Auditor and Client Tenure. Mid-American. Journal of Bussiness, 16 (2).

Soedibyo, A. N. (2010). Peran Nutrient Information dan Information Conciousness Dalam Memoderasi Hubungan Antara Job Satisfaction dan Turnover Intention di Kantor Akuntan Publik. Tesis. Universitas Indonesia, Jakarta.

Sulistiarini, Endina, \& Sudarno. (2012). Analisis Fakor- faktor Pergantian Kantor Akuntan Publik (Studi Empiris pada Perusahaan Manufaktur di Bursa Efek Indonesia Tahun 2006-2010). Jurnal Akuntansi. 1(2).

Suparlan \& Andayani, Wuryan. (2010). Analisis Empiris Pergantian Kantor Akuntan Publik Setelah Ada Kewajiban Rotasi Audit. Simposium Nasional Akuntansi XIII. IAI.

Surat Keputusan Menteri Negara/Kepala Badan Penanaman Modal dan Pembinaan BUMN No. 23/M PM/BUMN/2000 tentang Pengembangan Praktik GCG dalam Perusahaan Perseroan (PERSERO).

Suryanti, Lilik. (2014). Pengaruh Pergantian Manajemen, Kepemilikan Publik, Financial Distress, Ukuran KAP, Ukuran Perusahaan dan Opini Audit Terhadap Auditor Switching pada Perusahaan Industri Jasa di Bursa Efek Indonesia Tahun 2009-2013. Fakultas Ekonomi Universitas Pandanaran, Semarang.

Undang-Undang Nomor 5 Tahun 2011 Tentang Akuntan Publik.

Wijayani, Evy Dwi. (2011). Analisis Faktor-Faktor yang Mempengaruhi Perusahaan di Indonesia Melakukan Auditor Switching. Skripsi. Universitas Diponegoro, Semarang.

Wibisono, D. (2013). Panduan Penyusunan Skripsi, Tesis \& Disertasi. Yogyakarta : Penerbit Andi.

Wruck, K. H. (1990). Financial Distress, Reorganization, and Organizational Efficiency. Journal of Financial Economics. 